\title{
Strategi Membangun Brand Image dan Promosi dengan Sosial Media pada UMKM Jawet Sama Arep
}

\author{
Defri Triadi $^{1 *}$, Cristi Devi Darnita ${ }^{2}$ \\ 1,2 Institut Agama Kristen Negeri Palangka Raya \\ *email: defritriadi@iaknpky.ac.id
}

\begin{abstract}
Advances in technology make most people take advantage of its sophistication features. One of them is to create a media brand image of MSME products. Research develops social media as a means of branding. The research objectives are 1) to describe the condition of the brand image and promotion of MSMEs before using social media, 2) to explain the procedures for implementing the use of social media, and 3) to explain the results of the comparison after using social media. The object of this research is Jawet Sama Arep UMKM in Gohong Village, Pulang Pisau Regency, Central Kalimantan. Jawet Sama Arep is a local community group that produces woven rattan. This study uses a research and development approach. Data collection techniques are collected by collecting observations, information, product design, product design validation, design improvement, product trials, and product publications. The results show that the number of products produced since 2008-2019 has relatively increased and decreased in different years by looking at the opportunities for the rapid development of digital technology. Jawet Sama Arep develops promotional designs using social media such as Facebook, Instagram, Line, Youtube, Whatsapp, Telegram, and Twitter. This research can help realize the goals of SMEs as independent businesses. It is concluded that the achievement of brand image in the components of corporate image, user image, and product image by utilizing social media can be achieved well, compared to before using social media.
\end{abstract}

Keywords: brand image, promotion, media social

\begin{abstract}
Abstrak: Kemajuan teknologi membuat sebagian besar masyarakat memanfaatkan fitur kecanggihannya. Salah satunya yakni membuat media brand image dari produk UMKM. Penelitian mengembangkan media sosial sebagai sarana branding. Tujuan penelitian yaitu 1) mendeskripsikan kondisi brand image dan promosi UMKM sebelum memanfaatkan media sosial, 2) menjelaskan prosedur penerapan pemanfaatan media sosial, dan 3) menjelaskan hasil perbandingan sesudah menggunakan media sosial. Objek penelitian ini merupakan UMKM Jawet Sama Arep di Desa Gohong, Kabupaten Pulang Pisau, Kalimantan Tengah. Jawet Sama Arep merupakan kelompok masyarakat lokal yang memproduksi anyaman rotan. Penelitian menggunakan jenis pendekatan research and development. Teknik pengumpulan data dilakukan dengan mengumpulkan hasil observasi, mengumpulkan informasi, desain produk, validasi desain produk, perbaikan desain, uji coba produk, dan publikasi produk. Hasil penelitian menunjukkan jumlah produk yang diproduksi sejak tahun 2008-2019 relatif mengalami kenaikan dan juga penurunan di tahun yang berbeda, dengan melihat peluang perkembangan teknologi digital yang cukup pesat. Jawet Sama Arep mengembangkan desain promosi dengan menggunakan media sosial berupa Facebook, Instagram, Line, Youtube, Whatsapp, Telegram dan Twitter. Penelitian ini dapat membantu mewujudkan tujuan dari UMKM sebagai usaha mandiri. Disimpulkan bahwa capaian brand image pada komponen corporate image, user image, dan product image dengan memanfaatkan media sosial dapat tercapai dengan baik, dibandingkan sebelum menggunakan media sosial.
\end{abstract}

Kata kunci: brand image, promosi, sosial media

Copyright (c) 2021 The Authors. This is an open access article under the CC BY-SA 4.0 license (https://creativecommons.org/licenses/by-sa/4.0/) 


\section{PENDAHULUAN}

Perkembangan dan kemajuan zaman dewasa ini memasuki era digitalisasi, dimana hal tersebut menuju ke arah peradaban yang dinamis. Hal tersebut menjangkau seluruh aspek yang ada dalam kehidupan. Salah satunya pada aspek dunia kewirausahaan. Tidak hanya perkembangan teknologi modern saja yang mengalami kemajuan, melainkan kehidupan sosial pun bedampak dan dengan adanya perkembangan ini, masyarakat dikenal sebagai masyarakat modern. Masyarakat modern memanfaatkan kecanggihan teknologi selain untuk berkomunikasi dan mencari informasi, juga sebagai usaha dalam mengembangkan perekonomian. Hal ini dapat dilihat dari semakin meluasnya sistem jual beli yang dilakukan secara online. Selama satu dekade terakhir ini, media digital menjadi pilihan utama yang digunakan oleh para pemasar selain menjual produk juga membangun suatu brand. Peningkatan brand awareness dan brand image produk para perusahaan start up dan UMKM dapat ditunjang melalui Digital marketing. Penggunaan strategi pemasaran digital dalam meningkatkan brand image juga dituntut kreatif, khususnya dalam memasarkan sebuah produk. Hal tersebut memiliki tujuan agar produk yang mereka pasarkan dapat dengan mudah diingat serta diserap oleh pasar.

Kemajuan teknologi membuat sebagian besar masyarakat memanfaatkan fitur kecanggihannya. Salah satunya yakni membuat media brand image dari produk UMKM tersebut. Brand image yang dibangun oleh UMKM Jawet Sama Arep di Desa Gohong, Kabupaten Pulang Pisau ini memanfaatkan media sosial sebagai sarana dan upaya promosi menuju salah satu jenis usaha mandiri. Pertumbuhan pasar e-commerce di Indonesia yang meningkat $17 \%$ dalam beberapa tahun terakhir membuat Indonesia menjadi pasar potensial dalam bisnis digital. Fakta ini penting karena memungkinkan penjual untuk memperluas jaringan perdagangan penjualan (Haidar, 2016). Promosi merek melalui iklan online juga akan meningkatkan brand image karena pengguna media sosial dapat dengan mudah berinteraksi dengan orang lain. Selain itu, mereka dapat mempengaruhi orang lain dengan menyediakan testimoni positif (Tsimonis \& Sergios, 2014).

Media sosial telah mendatangkan suatu kebaharuan dalam komunikasi pemasaran yang menyediakan wadah baru untuk interaksi antara konsumen dan merek. Interaksi ini memiliki relevansi yang besar untuk merek karena pengguna jejaring sosial dapat melihat atau mempertimbangkan saran yang mereka terima dari pengguna lain (Schmitt et al., 2011), dan komunikasi tersebut akan memengaruhi proses pengambilan keputusan dalam 
pembelian (Hinz et al., 2011). Teknologi media sosial merupakan salah satu faktor pendukung dalam mengembangkan brand image suatu usaha dan penggunaan sarana teknologi informasi yang salah satunya adalah penggunaan sosial media pada UMKM di Indonesia menurut Dentoni dkk. dalam (Irianto, 2015). Implementasi teknologi informasi akan meningkatkan transformasi bisnis melalui kecepatan, ketepatan, dan efisiensi pertukaran informasi dalam jumlah yang besar. Peran media sosial di masa sekarang memang memudahkan individu dalam mengakses komunikasi dan informasi. Pada penelitian ini, media sosial seperti Facebook, Instagram, WhatsApp, Telegram, Line, dan Youtube menjadi sarana dalam mengembangkan profil dan produk UMKM. Media sosial dapat menjangkau masyarakat luas, sehingga hal ini dapat membantu mengembangkan brand image dari produk UMKM tersebut.

Brand image tidak dibuat dengan cepat dan membutuhkan upaya multipel yang berkelanjutan dalam jangka waktu yang lama. Saat ini, minat yang tumbuh dalam konsep manajemen merek bersama dengan berbagai persyaratan strategi pemasaran internasional di antara organisasi lintas sektor (Ökten et al., 2019). Brand image sangat berperan penting dalam sebuah usaha untuk meningkatkan penjualan produk dan pengenalan produk secara luas. Namun hal yang ditemui di lapangan terdapat usaha masyarakat dalam bentuk UMKM yang sudah mengikuti pameran secara nasional dan internasional namun masih menggunakan media konvesional untuk mempromosikan produk dan belum memiliki brand image. Hal tersebut yang mendorong penelitian ini dengan objek penelitian UMKM sebagai salah satu upaya untuk membangun brand image produk UMKM tersebut dengan menggunakan media sosial.

Pada penelitian ini, UMKM Jawet Sama Arep menjadi objek penelitian. Seorang pelaku usaha yaitu ibu Maryenie mendirikan UMKM Jawet Sama Arep di Desa Gohong, Kecamatan Kahayan Hilir, Kabupaten Pulang Pisau, Provinsi Kalimantan Tengah. UMKM mempunyai peranan dalam pembangunan ekonomi nasional. UMKM berperan dalam pertumbuhan ekonomi dan penyerapan tenaga kerja. Produk bisnis yang dikembangkan pada UMKM dalam penelitian ini berupa hasil kerajinan tangan seperti, tikar, topi, tas, dan lainlain. Inovasi ini terus dikembangkan melihat sumber bahan utama pembuatan kerajinan tersebut dapat dengan mudah ditemukan di lingkungan sekitarnya, maka usaha ini dapat berjalan dengan baik. 
Fenomena menarik yang peniliti observasi sebagai latar permasalahan penelitian ini yakni UMKM Jawet Sama Arep belum maksimal dalam memanfaatkan media sosial sebagai upaya untuk meningkatkan baik brand image maupun promosi produknya. Tentunya hal ini teramat disayangkan, sebab dengan memanfaatkan media sosial sebagai brand image dan promosi, UMKM dapat menuju usaha mandiri. Globalisasi pasar menuntut adanya peningkatan daya saing antar pelaku bisnis, menuntut para pelaku bisnis untuk meningkatkan, mendesain ulang dan memodifikasi strategi bersaingnya. Begitu juga dengan UMKM yang dituntut untuk dapat mengikuti perkembangan pasar agar dapat bertahan dan meningkatkan brand image UMKM tersebut. Berdasarkan hal tersebut, penelitian ini bertujuan sebagai berikut: 1) mendeskripsikan kondisi brand image dan promosi UMKM sebelum memanfaatkan media sosial, 2) menjelaskan prosedur penerapan pemanfaatan media sosial, dan 3) menjelaskan hasil perbandingan sesudah menggunakan media sosial.

Kotler \& Keller, (2016) mendefinisikan brand image sebagai seperangkat keyakinan, ide, dan kesan yang dimiliki seorang terhadap suatu merek. Sikap dan tindakan konsumen terhadap suatu merek sangat di tentukan oleh brand image merupakan syarat dari merek yang kuat. Brand image didefinisikan sebagai persepsi konsumen dalam ingatan mereka tentang merek yang direfleksikan sebagai asosiasi merek Rindell \& Oriol, (2014). Brand image juga dianggap sebagai salah satu aset tak berwujud terpenting yang berdampak pada persepsi konsumen di perusahaan. Ada dua komponen utama citra merek yaitu dimensi fungsional dan afektif. Dimensi fungsional merupakan dimensi yang memiliki karakteristik berwujud yang terukur. Sedangkan dimensi afektif adalah tentang psikologis melalui perasaan dan sikap terhadap perusahaan (Martínez, Patricia, Andrea, P., and Ignacio, 2014). Perusahaan melakukan pengembangan citra merek serta perluasan portofolio merek. Dengan memperluas portofolio merek mereka ke produk baru, mereka bisa mendapatkan keuntungan dari citra dan kesadaran merek yang sudah mapan. Selain itu, hal ini juga dapat membuat lebih banyak calon pelanggan sadar akan citra merek mereka (Kremer \& Catherine, 2012).

Berbagai jenis alat pemasaran yang dapat digunakan dalam proses penciptaan brand image suatu produk diantara lain kemasan/label, nama merek, logo, warna, promosi pembelian, retail, iklan, harga, pemilik merek, negara asal produk tersebut, bahkan konsumen dan pengguna produk tersebut. Komponen pembentuk brand image ada 3, yaitu : 1) Citra Pembuat; 2) Citra Pemakai; dan 3) Citra Produk. Peningkatan brand image dalam meningkatkan penjualan dalam penelitian ini didukung oleh penelitian sebelumnya yang 
dilakukan oleh Sudarwati \& Satya (2013) yang menunjukkan bahwa untuk menciptakan keunggulan kompetitit dan dapat bersaing di pasar global maka UMKM harus melakukan branding. Dengan terciptanya brand image dari suatu produk maka orang akan lebih mengenal dan mengingat citra dari produk tersebut sehingga akan lebih mudah dikenal masyarakat luas.

Kegiatan promosi merupakan suatu alat komunikasi antara perusahaan dan pengguna, tidak hanya itu promosi merupakan alat untuk mempengaruhi kegiatan pembelian oleh pengguna sesuai dengan keinginan dan kebutuhannya. Manfaat lain dari promosi penjualan dapat dicapai dengan menarik perhatian konsumen dan memengaruhi keputusan pembelian mereka (Hanaysha, 2018). Promosi dianggap sebagai elemen kunci bauran pemasaran yang bertujuan untuk menginformasikan, mendorong, dan mengingatkan pengguna tentang suatu produk penawaran jasa dalam upaya untuk mempengaruhi perasaan, persepsi, atau keputusan pembelian konsumen (Stanton, W.J. et al., 2007). Kegiatan promosi untuk meningkatkan penjualan dalam penelitian ini didukung oleh penelitian sebelumnya yang dilakukan oleh Harini et al. (2017) yang menunjukkan bahwa internet marketing dan e-commerce merupakan aspek penting dari promosi karena dapat menjangkau seluruh konsumen dipenjuru dunia.

Sosial media merupakan suatu alat komunikasi berbiaya minimal dengan waktu fleksibel yang berguna dalam proses interaksi pemasar dan pengguna. Implementasi pemasaran media sosial yang efektif adalah salah satu tujuan utama dan kepentingan beberapa merek (Hanaysha, 2016). Kaplan \& Haenlein (2010) mengkonseptualisasikan media sosial sebagai program berbasis internet yang menyediakan platform bagi konsumen untuk mengekspresikan pendapat mereka sendiri, berbagi informasi dan pengalaman masa lalu menggunakan berbagai jejaring sosial, blog, dan area konten lainnya. Efisiensi media sosial telah memberdayakan pemasar dan pelanggan dengan interaksi cepat dan proses komunikasi untuk meningkatkan layanan pelanggan, meningkatkan kesadaran merek dan membangun hubungan pelanggan-merek yang kuat. Penggunaan media sosial dapat memudahkan konsumen dalam mengungkapkan pendapat mereka kepada lebih banyak individu dan menemukan informasi yang diinginkan dengan cepat tanpa menimbulkan banyak biaya (Severi et al., 2014). Penggunaan sosial media untuk menjangkau lebih banyak konsumen dalam penelitian ini di dukung oleh penelitian sebelumnya yang dilakukan oleh Irianto (2015) yaitu pemanfaatan sosial media untuk meningkatkan market share UMKM. 


\section{METODE PENELITIAN}

Penelitian ini merupakan jenis penelitian dan pengembangan atau research and development (R\&D). Menurut Sugiyono (2016) research and development adalah metode penelitian yang diperuntukkan dalam menghasilkan produk tertentu serta menguji keefektifan produk tersebut. Produk yang dihasilkan dalam penelitian ini adalah berupa desain brand image pada UMKM dan menguji keefektifan desain brand image tersebut melalui promosi pada media sosial.

Tim Puslitjaknov (2008), mengemukakan prosedur penelitian pengembangan menurut Borg \& Gall dapat disederhanakan menjadi lima langkah utama yaitu:

1) Melakukan analisis kebutuhan produk yang akan dikembangkan

2) Mengembangkan produk awal

3) Vaidasi ahli dan revisi

4) Uji coba lapangan skala kecil dan revisi produk

5) Uji coba lapangan skala besardan produk akhir

Objek pada penelitian yakni kegiatan UMKM yang berlokasi di Desa Gohong, Kecamatan Kahayan Hilir, Kabupaten Pulang Pisau, Provinsi Kalimantan Tengah. Teknik pengumpulan data dilakukan dengan cara observasi, angket dan dokumentasi. Teknik analisis data yaitu dengan analisis deskriptif. Instrumen penelitian dilakukan dengan menerapkan prosedur penilian sebagai berikut:

Tabel 1. Instrumen Penilaian

\begin{tabular}{|c|c|c|c|c|c|c|c|}
\hline \multirow[t]{2}{*}{ No. } & \multirow[t]{2}{*}{ Aspek Kriteria } & \multirow[t]{2}{*}{ Indikator } & \multicolumn{5}{|c|}{ Nilai } \\
\hline & & & SK & $\mathbf{K}$ & $\mathbf{N}$ & B & SB \\
\hline \multirow[t]{8}{*}{1.} & \multirow{8}{*}{$\begin{array}{l}\text { Tampilan desain visual } \\
\text { ataupun audio produk } \\
\text { UMKM }\end{array}$} & $\begin{array}{l}\text { kesesuaian antara rancangan desain } \\
\text { dengan produk yang dikembangkan. }\end{array}$ & & & & & \\
\hline & & b. desain produk tidak terlalu norak. & & & & & \\
\hline & & $\begin{array}{l}\text { c. desain produk mengikuti trend } \\
\text { brand image di media sosial. }\end{array}$ & & & & & \\
\hline & & $\begin{array}{ll}\text { d. bentuk desain produk tidak } \\
\text { mencolok. }\end{array}$ & & & & & \\
\hline & & $\begin{array}{l}\text { e. } \begin{array}{l}\text { rancangan desain produk dapat } \\
\text { dipahami. }\end{array}\end{array}$ & & & & & \\
\hline & & $\begin{array}{l}\text { f. desain produk dibuat sesuai dengan } \\
\text { nilai jual produk UMKM. }\end{array}$ & & & & & \\
\hline & & $\begin{array}{l}\text { g. audio dalam desain iklan produk } \\
\text { UMKM jelas didengar. }\end{array}$ & & & & & \\
\hline & & $\begin{array}{l}\text { h. Tidak menambahkan efek audio } \\
\text { yang berlebihan }\end{array}$ & & & & & \\
\hline \multirow[t]{2}{*}{2.} & \multirow[t]{2}{*}{ Jenis media social } & a. Facebook & & & & & \\
\hline & & b. Instagram & & & & & \\
\hline
\end{tabular}




\begin{tabular}{|c|c|c|}
\hline & & c. Whatsapp \\
\hline & & d. Line \\
\hline & & e. Telegram \\
\hline & & f. Youtube \\
\hline & & g. $\quad$ Twitter \\
\hline 3. & Kesusaian Materi Produk & $\begin{array}{l}\text { a. tingkat keseuaian materi desain } \\
\begin{array}{l}\text { dengan produk UMKM dinilai } \\
\text { sesuai. }\end{array}\end{array}$ \\
\hline & & $\begin{array}{l}\text { b. materi produk yang digunakan tidak } \\
\text { menyimpang dari SARA. }\end{array}$ \\
\hline & & $\begin{array}{l}\text { c. materi desain sesuai dengan fungsi } \\
\text { dari produk UMKM }\end{array}$ \\
\hline
\end{tabular}

\section{HASIL DAN PEMBAHASAN Profil UMKM}

UMKM Jawet Sama Arep merupakan kelompok masyarakat lokal yang memproduksi anyaman rotan. UMKM Jawet Sama Arep berdiri pada tanggal 14 April 2008 dengan beranggotakan 15 orang sekarang ini. Dalam menjalankan usahanya, UMKM Jawet Sama Arep memiliki visi yaitu menjadi UMKM kelompok anyaman rotan yang maju dan sukses. Untuk mencapai visi tersebut, UMKM Jawet Sama Arep memiliki misi, yaitu meningkatkan standart produksi dan kualitas produksi, memperluas jaringan pemasaran di seluruh Indonesia dan luar negeri, dan meningkatkan kesejahteraan anggota kelompok. UMKM Jawet Sama Arep memproduksi berbagai macam kerajinan rotan, seperti tas, topi, tikar, lawung, gelang serta menerima pesanan sesuai dengan keinginan. Proses pembuatan kerajinan anyaman rotan ini dilakukan seminggu sekali, yaitu setiap hari sabtu.

Hasil

Temuan atau data yang berkaitan dengan hasil penelitian, sesuai dengan prosedur penelitian yang telah disusun. Penulis memaparkan tentang hasil studi pendahuluan, pengembangan rancangan media desain model penelitian, validasi media desain penelitian, hasil uji coba desain media, serta perbandingan hasil uji coba sebelum dan sesudah menggunakan media. Sebelumnya, penulis kembali mengingatkan bahwa objek penelitian ini merupakan UMKM Jawet Sama Arep di Desa Gohong, Kabupaten Pulang Pisau, Kalimantan Tengah. Adapun hasil produksi dari UMKM Jawet Sama Arep antara lain:

Tabel 1. Hasil Produksi UMKM Jawet Sama Arep

\begin{tabular}{ccc}
\hline No & Bahan Produksi & Hasil Produksi \\
\hline $\mathbf{1}$ & Rotan & Tas \\
\hline $\mathbf{2}$ & Rotan & Topi \\
\hline $\mathbf{3}$ & Rotan & Tikar \\
\hline $\mathbf{4}$ & Rotan & Lawung \\
\hline
\end{tabular}


Rotan
$\begin{aligned} & \text { Sumber }: \text { Data diolah, } 2020 \\ & \text { Hasil dari produksi tersebut dipasarkan baik secara lokal maupun ke luar daerah. }\end{aligned}$ Selain memproduksi kerajinan tersebut, UMKM ini juga dapat menerima pesanan sesuai dengan keinginan. Berdasarkan informasi yang diperoleh dari pengurus UMKM Jawet Sama Arep bahwa jumlah produk yang diproduksi sejak tahun 2008- 2019 relatif mengalami kenaikan dan juga penurunan di tahun yang berbeda. Berdasarkan hal tersebut pengelola UMKM membuat penelitian dengan mengembangkan media brand image dengan untuk dapat mengenalkan produk UMKM Jawet Sama Arep, juga dapat menaikan produksi dari hasil UMKM tersebut. Berikut grafik jumlah produksi UMKM Jawet Sama Arep, yaitu:

\section{Gambar 1. Grafik Hasil Produksi}

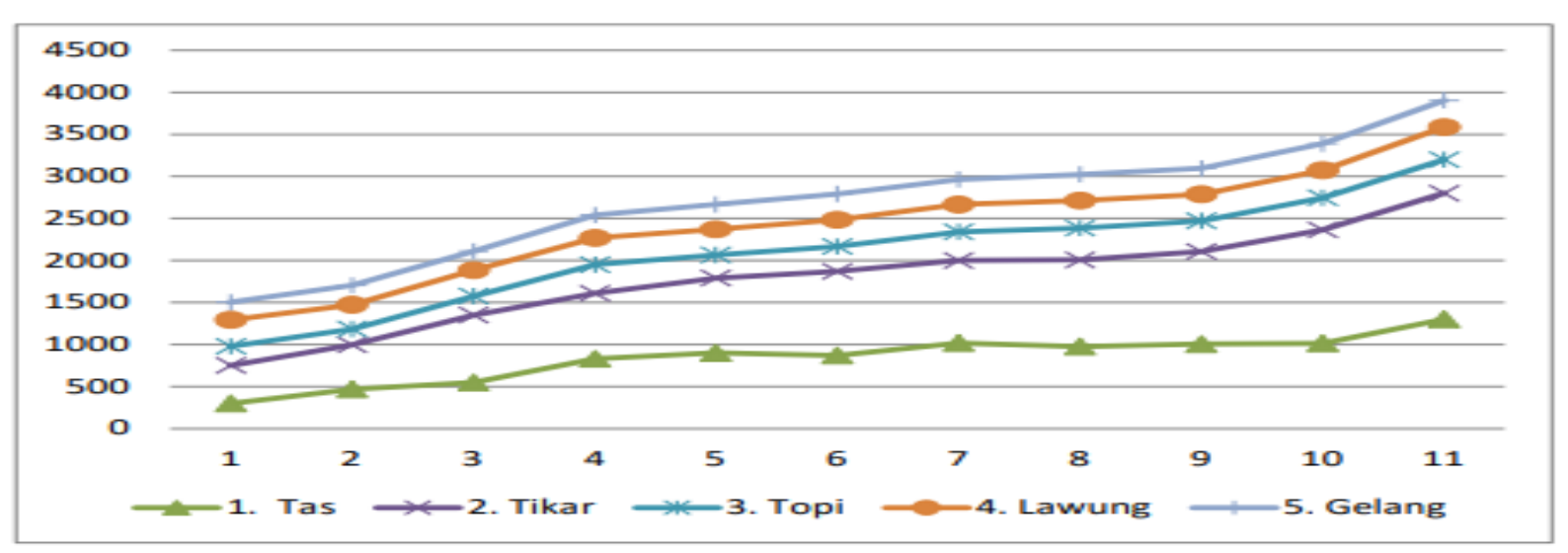

Sumber : Data produksi periode 2008-2019, 2020

Konsumen lebih sering membeli produk dengan merek yang dikenal karena adanya asumsi bahwa merek terkenal lebih dapat diandalkan, selalu tersedia dan mudah dicari, dan memiliki kualitas yang tidak diragukan, sehingga merek yang lebih dikenal lebih sering dipilih konsumen daripada merek yang tidak terkenal. Hal inilah yang menjadikan tantangan tersendiri bagi komunitas UMKM Jawet Sama Arep. Hasil produksi UMKM ini masih belum memiliki brand image, namun dengan melakukan penelitian pengembangan media promosi ini dapat membantu membangun brand image lokal untuk UMKM Jawet Sama Arep. Jika ditinjau dari komponen penyususn brand image sendiri, maka dibutuhkan tiga pilar komponen utama antara lain:

Tabel 2. Komponen Brand Image UMKM Jawet Sama Asep No Komponen Brand Image Capaian Berdasarkan Komponen Corporate Image User Image Product Image 


\begin{tabular}{|c|c|c|c|}
\hline 1 & $\begin{array}{l}\text { UMKM Jawet Sama Arep } \\
\text { merupakan asosiasi } \\
\text { masyarakat lokal yang membuat } \\
\text { produksi hasil dari bahan baku } \\
\text { rotan yang merupakan khas dari } \\
\text { daerah Desa Gohong, Kabupaten } \\
\text { Pulang Pisau, Kalimantan Tengah. } \\
\text { Tujuan dari UMKM ini sendiri } \\
\text { membantu meningkatkan } \\
\text { perekonomian Desa dengan } \\
\text { menjual produk lokal UMKM } \\
\text { tersebut. }\end{array}$ & $\begin{array}{l}\text { Pada mulanya pengguna produksi } \\
\text { UMKM Jawet Sama Arep hanya } \\
\text { dari lingkungan masyarakat lokal. } \\
\text { Namun, pada tahun 2012, } \\
\text { pengembang UMKM mulai } \\
\text { melakukan promosi brand image } \\
\text { dengan memanfaatkan } \\
\text { kecanggihan teknologi, salah } \\
\text { satunya dengan memanfaatkan } \\
\text { Facebook. Sehingga, dapat } \\
\text { menjangkau konsumen lebih jauh. }\end{array}$ & $\begin{array}{l}\text { Adapun hasil produk } \\
\text { dari UMKM memiliki } \\
\text { nilai positif bagi } \\
\text { konsumen, salah satunya } \\
\text { bahan baku yang } \\
\text { digunakan tidak menjadi } \\
\text { polusi. }\end{array}$ \\
\hline 2 & $\begin{array}{lr}\text { Peran masyarakat Desa } & \text { Gohong, } \\
\text { Kabupaten Pulang } & \text { Pisau, } \\
\text { Kalimantan Tengah } & \text { dalam } \\
\text { mempromosikan } & \text { hasil } \\
\text { produksinya. } & \end{array}$ & $\begin{array}{l}\text { Wisatawan yang berkunjuang ke } \\
\text { Desa Gohong, Kabupaten Pulang } \\
\text { Pisau, Kalimantan Tengah juga } \\
\text { melirik produksi rotan seperti tas } \\
\text { atau topi dari UMKM Jawet Sama } \\
\text { Arep. }\end{array}$ & $\begin{array}{l}\text { Pemanfaatan rotan } \\
\text { menjadi ciri khas dari } \\
\text { Indonesia, sehingga hal } \\
\text { ini bisa menjadi peluang } \\
\text { ekonomi untuk produk } \\
\text { dengan nilai jual ekspor. }\end{array}$ \\
\hline
\end{tabular}

Dalam menciptakan brand image UMKM Jawet Sama Arep terdapat beberapa komponen yang perlu dibuat sebagai penunjang dalam menciptakan brand image, antara lain melalui:

1) Logo merupakan suatu gambar atau sketsa yang memiliki makna, ciri dan karakter dari UMKM Jawet Sama Arep.

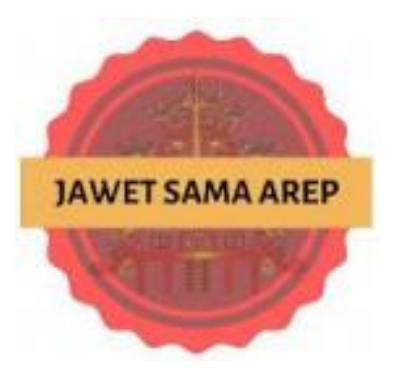

\section{Gambar 2. Logo UMKM Jawet Sama Arep}

Gambar tersebut merupakan logo UMKM Jawet Sama Arep yang berfilosofi kehidupan masyarakat dayak, dan tulisan Jawet Samas Arep memiliki makna yaitu bekerja sama. Melalui logo tersebut menjadi identitas UMKM Jawet Sama Arep sehingga mudah dikenal masyarakat luas.

2) Kemasan/Label yang dirancang pada produk UMKM Jawet Sama Arep di desain secara kreatif dengan bentuk dan warna yang unik sehingga dapat membangun brand image dan mendorong penjualan, contohnya paperbag atau dustbag yang digunakan untuk membungkus produk. Label yang terdapat pada produk UMKM Jawet Sama Arep merupakan salah satu bagian dalam pengembangan brand 
image yang berisikan tentang informasi yang perlu dicantumkan dan untuk diketahui, contohnya logo dan No kontak. Jadi kedua hal di atas merupakan alat pemasaran yang dapat digunakan untuk menciptakan brand image.

Media pengembangan promosi brand image UMKM Jawet Sama Arep pada proses ini penulis melakukan desain pengembangan media terlebih dahulu adapun desain yang dilakukan disesuaikan dengan kondisi penelitian yakni:

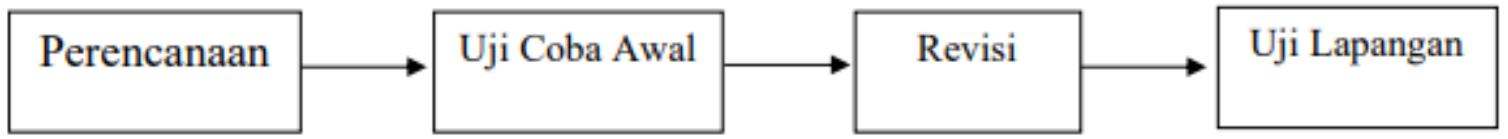

\section{Gambar 3. Proses Pengembangan Media}

1) Pada tahap ini perencanaan rancangan meliputi langkah apa saja yang perlu dipersiapkan dalam membangun brand image serta membuat media promosi. Adapun langkah yang digunakan untuk membangun brand image yakni melalui tiga komponen brand image yaitu corporate image, user image, product image serta dengan membuat logo dan kemasan/label sebagai penunjang brand image. Langkah selanjutnya yaitu dengan membuat media sosial yang sedang populer.

2) Pada tahap ini uji coba awal dilakukan dengan menyusun konsep brand image sesuai dengan tiga komponen yang telah ditentukan. Pada tahap selanjutnya mempublikasikan produk UMKM pada media sosial facebook dan instagram. Berdasarkan data pengamatan yang diperoleh dari kunjungan klik pada akun Facebook dan Instagram UMKM Jawet Sama Arep cenderung lebih banyak diakses pada akun Instagram. Adapun perbandingan jangkauannya sebanyak $60 \%$ user mengakses pada akun Instagram, dan sebanyak $40 \%$ user mengakses pada akun Facebook. Berdasarkan hasil uji coba awal pada media sosial facebook dan instagram tersebut, maka pengembangan media sosial dilakukan pada twitter, youtube, telegram, line dan whatsapp.

3) Revisi pada tahap revisi ini, dalam membangun brand image masih perlu adanya perbaikan pada desain produk serta pengembangaan media perlu sedikit perbaikan terutama dalam hal konsep penyajian. Dengan menggunakan media sosial untuk promosi brand image suatu produk juga dibutuhkan konsep promosi. Setelah dilakukan uji coba awal, pengembangan media promosi pada produk UMKM Jawet Sama Arep diperlukan revisi untuk konsep penyajian materi produk.

4) Uji Lapangan maka setelah dilakukan penilaian dari proses uji coba awal pengembangan media sosial sebagai brand image produk UMKM Jawet Sama Arep, maka selanjutnya 
adalah tahap uji lapangan, berikut merupakan hasil dari pengembangan media sosial dari UMKM Jawet Sama Arep:

a) Promosi melalui media sosial facebook

Gambar di bawah memperlihatkan tampilan profil facebook dimanfaatkan sebagai media pemasaran dan promosi online guna mengembangkan brand image dari UMKM Jawet Sama Arep, melalui fanpage khusus sehingga usaha bisa berkembang dengan pesat, efektif dan efisien.

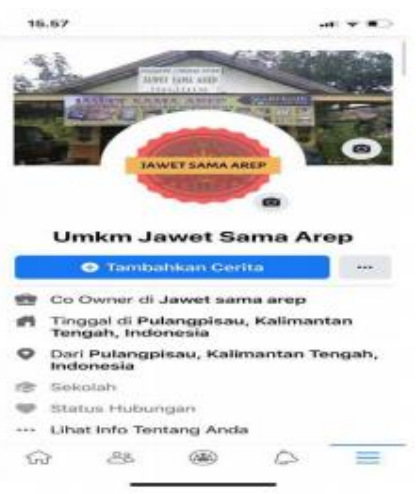

\section{Gambar 4 Tampilan Profil Facebook UMKM Jawet Sama Arep}

b) Promosi melalui media sosial instagram

Promosi melalui media sosial instagram dinilai menjadi salah satu media sosial yang lebih unggul dari lainnya, yang dimana banyak dimanfaatkan para pelaku usaha maupun perusahaan untuk membantu mempromosikan produk dan jasanya.

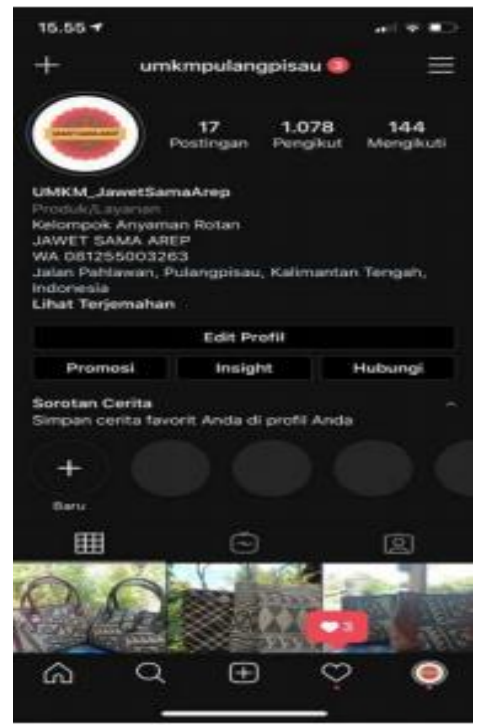

Gambar 5. Profil instagram UMKM Jawet Sama Arep 
Instagram dinilai menjadi salah satu media sosial yang lebih unggul dari lainnya, yang dimana banyak dimanfaatkan para pelaku usaha maupun perusahaan untuk membantu mempromosikan produk dan jasanya. Instagram digunakan untuk mengupload foto dan video produk dari UMKM Jawet Sama Arep sebagai sarana pengembangan brand image serta mampu menjadi katalog hasil produksi dalam menjalankan komunikasi pemasaran. Fitur lainnya yang dimanfaatkan UMKM Jawet Sama Arep dalam proses pengembangan brand image yaitu followers, comment, like, hashtag, location, caption, dan tagging.

c) Promosi melelaui Media Sosial Twitter

Media promosi selanjutnya adalah twitter, media ini memiliki daya tarik yang cukup populer tentunya di kalangan milenial. Media sosial twitter digunakan untuk mempromosikan hasil produk dari UMKM Jawet Sama Arep, serta sebagai kegiatan pemasaran yang membangun ingatan dan tindakan terhadap merk atau produk seperti terlihat pada gambar 6 yang meperlihatkan tampilan profil UMKM Jawet sama Arep dalam bentuk twitter.

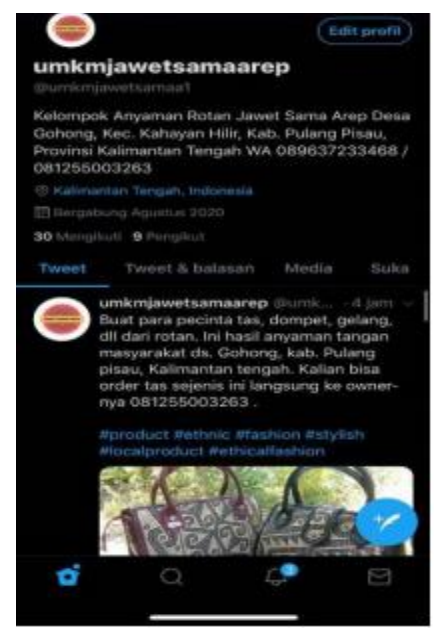

\section{Gambar 6 . Tampilan Profil Twitter UMKM Jawet Sama Arep}

Konten-konten yang bisa dimanfaatkan dengan pada twitter adalah following, tweeting, replies, retweet, dan trending topics. Hal ini bisa dimanfaatkan pelaku usaha untuk memaksimalkan promosi produknya. Media sosial twitter didaftarkan menggunakan email UMKM Jawet Sama Arep. Dengan adanya media sosial twitter UMKM Jawet Sama Arep dapat bersaing dalam jualan online. 
d) Promosi melalui Media Sosial Youtube

Youtube merupakan saluran sosial media yang memungkinkan orang diseluruh dunia untuk berinteraksi, berbagi, dan membuat konten melalui komunitas online.

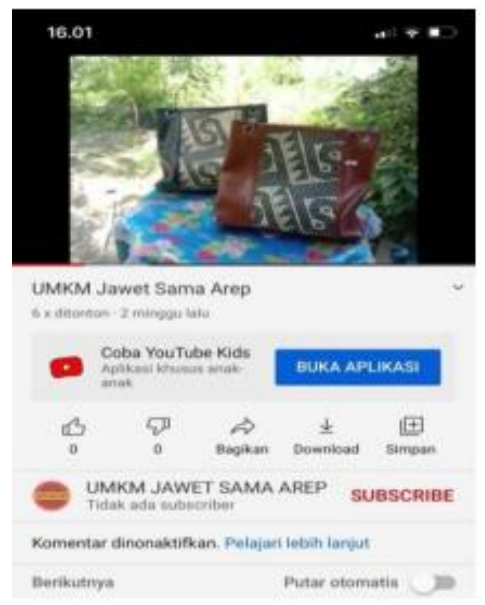

\section{Gambar 7. Tampilan Profil Youtube UMKM Jawet Sama Arep}

Pada gambar 7 terdapat tampilan profil youtube UMKM Jawet Sama Arep. Youtube UMKM Jawet Sama Arep, digunakan untuk mempromosikan produk, mengungkapkan kepribadian brand image, memantau feedback, memberikan layanan kostumer dan membantu kostumer menyebarkan berita tentang usaha. Melalui youtube, UMKM Jawet Sama Arep telah mengupload video katalog produk dari hasil olahan rotan, serta menampilkan cara menganyam rotan dalam proses pembuatan produk.

e) Promosi melalui media sosial telegram

Telegram ialah salah satu akun media sosial yang digunakan oleh UMKM Jawet Sama Arep untuk mendistribusikan konten-konten pemasaran. Konten pemasaran dapat berupa teks, audio maupun video. Telegram memiliki kemampuan mengirim file lebih besar dari aplikasi chat lain hingga $2 \mathrm{~Gb}$.

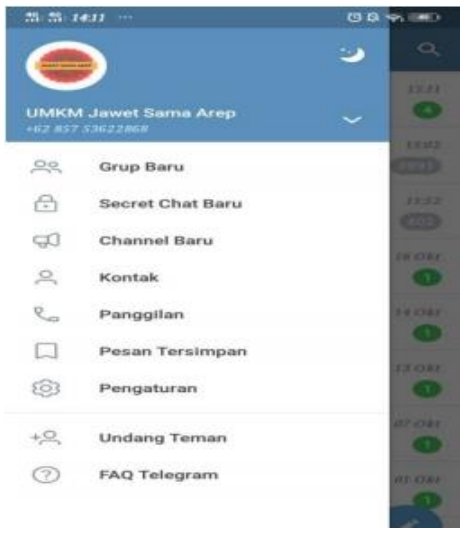




\section{Gambar 8. Tampilan Profil Telegram UMKM Jawet Sama Arep}

Telegram yang dimanfaatkan oleh UMKM Jawet Sama Arep digunakan sebagai sarana komunikasi dengan konsumen dalam berinteraksi serta memperomosikan semua hasil produk melalui group UMKM Nasional dan Internasional, sehingga produk dapat dikenal secara luas. Saat ini telegram juga tersedia disemua sistem operasi utama, termasuk windows, macOS, android, iOS dan linux serta tersedia versi web.

f) Promosi melalui media sosial Line

Line merupakan sebuah aplikasi instant messaging asal Jepang, yang dapat digunakan untuk mengirim pesan, gambar, foto, video, suara, share location dan membuat album foto untuk berbagi momen bersama teman dan keluarga. Fitur-fitur yang terdapat dalam line mendukung pengguna dalam mengembangkan brand image dan promosi dari UMKM Jawet Sama Arep. Line yang dimanfaatkan UMKM Jawet Sama Arep sebagai sarana komunikasi antara penjual dan pembeli. Dengan menggunkan line pelaku usaha dapat berinteraksi secara langsung dengan .pembeli serta dapat mengirimkan boardcast message terkait produk yang sedang mereka pasarkan. Adanya boardcast ini sangat membantu pelaku usaha menawarkan produknya kepada para konsumen untuk informasi produk terbaru.

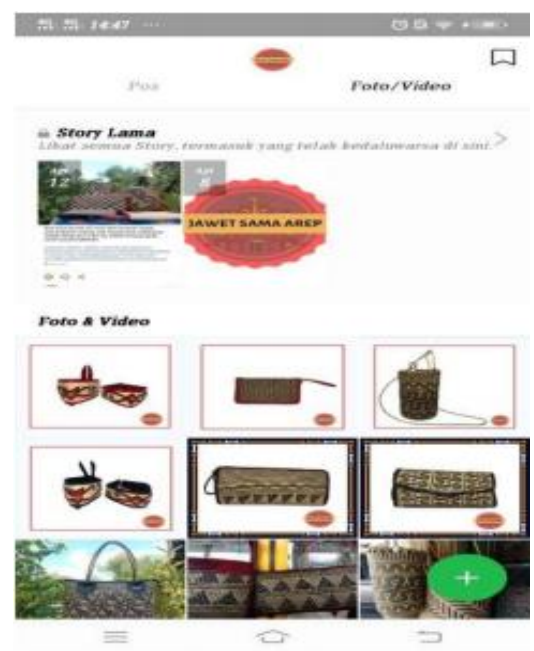

Gambar 9. Tampilan Profil Line UMKM Jawet Sama Arep

Pada Gambar 9 ditampilkan profil line UMKM Jawet Sama Arep yang digunakan untuk menunjang promosi produk. Melalui media sosial line ini juga sebagai sarana alternatif pemesanan produk. 
g) Promosi melalui media sosial Whatsapp

Whatsapp merupakan aplikasi yang di desain secara khusus untuk memudahkan para pemilik usaha dalam menjalankan usahanya, salah satu manfaat whatsapp untuk pemasaran bisnis online ialah sebagai sarana komunikasi dengan para pelanggan. Dalam dunia bisnis komunikasi merupakan hal yang sangat penting agar terjadinya interaksi antara penjual dan pembeli.

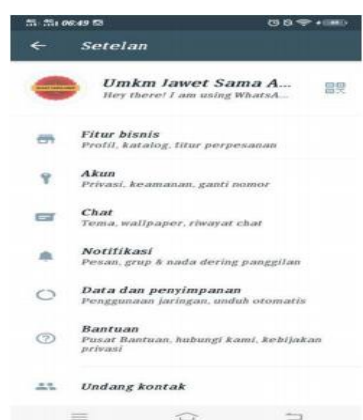

\section{Gambar 10. Tampilan Profil Whatsapp UMKM Jawet Sama Arep}

Whatsapp yang dimanfaatkan UMKM Jawet Sama Arep digunakan sebagai media interaksi antara penjual dan pembeli, sehingga dapat menjangkau pelanggan lebih cepat dengan cara efisien. Di sisi lain melalui whatsapp dapat berbagi titik koordinat lokasi yang dapat membantu pelanggan untuk mengunjungi UMKM Jawet Sama Arep. Kemudian membuat group untuk mendorong pemasaran lebih mudah sehingga memperkenalkan produk-produk UMKM Jawet Sama Arep.

\subsubsection{Hasil Analisis Kriteria Penilaian Aspek Tampilan Desain Media}

Pada aspek kriteria tampilan desain media baik berupa visual maupun audio terdapat indikator penilaian yakni: (1) kesesuaian antara rancangan desain dengan produk yang dikembangkan; (2) desain produk tidak terlalu norak; (3) desain produk mengikuti trend brand image di media sosial; (4) bentuk desain produk tidak terlalu mencolok; (5) rancangan desain produk dapat dipahami; (6) desain produk dibuat sesuai dengan nilai jual UMKM; (7) komposisi audio dan visual jelas; (8) tidak menambahkan efek audio dan visual berlebihan.

Berdasarkan indikator tersebut hasil analisis uji yang digunakan yakni mengukur nilai kurtosis dari data penilaian berdasarkan kriteria tampilan desain audio dan visual produk UMKM Jawet Sama Arep. Nilai kurtosis merupakan hasil ukur pada puncak dari distribusi data (Sugiyono, 2016). 
Tabel 3. Data Deskriptif Uji Kurtosis pada Aspek Penilaian Tampilan Desain Media

\begin{tabular}{|c|c|c|c|c|c|c|c|c|c|c|}
\hline & $\mathrm{N}$ & Range & $\begin{array}{c}\text { Minimu } \\
\mathrm{m}\end{array}$ & $\begin{array}{c}\text { Maximu } \\
\mathrm{m}\end{array}$ & Sum & Mean & $\begin{array}{c}\text { Std. } \\
\text { Deviation }\end{array}$ & $\begin{array}{c}\text { Varianc } \\
\mathrm{e}\end{array}$ & \multicolumn{2}{|c|}{ Kurtosis } \\
\hline & $\begin{array}{c}\text { Statisti } \\
\mathrm{c} \\
\end{array}$ & $\begin{array}{c}\text { Statisti } \\
\mathrm{c} \\
\end{array}$ & Statistic & Statistic & Statistic & Statistic & Statistic & Statistic & Statistic & $\begin{array}{l}\text { Std. } \\
\text { Error }\end{array}$ \\
\hline kriteria_1 & 33 & 2 & 3 & 5 & 138 & 4,18 &, 528 & ,278 & ,350 & ,798 \\
\hline kriteria_2 & 33 & 2 & 3 & 5 & 132 & 4,00 & ,661 & ,437 &,- 546 & ,798 \\
\hline kriteria_3 & 33 & 3 & 2 & 5 & 136 & 4,12 & ,781 & ,610 & 1,727 & 798 \\
\hline kriteria_4 & 33 & 2 & 3 & 5 & 121 & 3,67 & ,645 & ,417 &,- 601 & ,798 \\
\hline kriteria_5 & 33 & 1 & 4 & 5 & 139 & 4,21 & ,415 &, 172 & , 187 & ,798 \\
\hline kriteria_6 & 33 & 2 & 3 & 5 & 132 & 4,00 &, 500 & ,250 & 1,523 & ,798 \\
\hline kriteria_7 & 33 & 3 & 2 & 5 & 123 & 3,73 & ,761 & , 580 & , 167 & 798 \\
\hline kriteria_8 & 33 & 2 & 3 & 5 & 123 & 3,73 &, 574 & 330 &,- 375 & ,798 \\
\hline Valid N & & & & & & & & & & \\
\hline (listwise) & 33 & & & & & & & & & \\
\hline
\end{tabular}

Sumber: Hasil Olah Data SPSS 23, 2020

Berdasarkan hasil output uji statistik deskriptif pada tabel 3 menunjukkan jumlah responden $(\mathrm{N})$ sebanyak 33 orang dengan memberikan penilaian terendah (minimum) 2 pada indikator desain produk tidak terlalu norak dan komposisi audio dan visual jelas, yang artinya desain masih dinilai norak dan komposisi audio dan visual dinilai masih kurang jelas. Sedangkan pada hasil uji kurtosis menunjukkan dua aspek kriteria penilaian belum berdistribusi secara baik yakni pada indikator desain produk mengikuti trend brand image di media sosial $=1,727$ dan desain produk dibuat sesuai dengan nilai jual UMKM = 1,523. Seperti yang diketahui bahwa nilai kurtosis yang berdistribusi dengan baik jika hasil uji statistik semakin mendekati angka 0. Sedangkan kedua indikator pada aspek kriteria penilaian tersebut lebih besar dari nilai 0, sehingga dapat disimpulkan kedua indikator tersebut belum berdistribusi dengan baik.

\subsubsection{Hasil Analisis Kriteria Penilaian Aspek}

Jenis-Jenis Media Sosial Media sosial menjadi salah satu topik yang paling populer di zaman digital ini, selain fungsinya dijadikan sebagai saran komunikasi secara virtual, kegunaanya pun sudah dapat dijadikan sebagai media pendukung perekonomian. Salah satunya yang dilakukan oleh UMKM Jawet Sama Arep yang mengembangkan jenis-jenis media sosial. Berikut merupakan hasil analisis uji yang digunakan yakni mengukur nilai kurtosis dari data penilaian berdasarkan jenis-jenis media sosial yang dikembangkan oleh UMKM Jawet Sama Arep. 
Tabel 4. Descriptive Statistics Jenis-jenis Media Sosial

\begin{tabular}{|c|c|c|c|c|c|c|c|c|c|c|c|}
\hline & $\mathrm{N}$ & $\begin{array}{c}\text { Rang } \\
\mathrm{e} \\
\end{array}$ & $\begin{array}{c}\text { Minim } \\
\text { um }\end{array}$ & $\begin{array}{c}\text { Maxim } \\
\text { um }\end{array}$ & Sum & \multicolumn{2}{|c|}{ Mean } & $\begin{array}{c}\text { Std. } \\
\text { Deviation }\end{array}$ & $\begin{array}{c}\text { Varia } \\
\text { nce }\end{array}$ & \multicolumn{2}{|c|}{ Kurtosis } \\
\hline & $\begin{array}{c}\text { Statis } \\
\text { tic }\end{array}$ & $\begin{array}{c}\text { Statist } \\
\text { ic } \\
\end{array}$ & $\begin{array}{c}\text { Statist } \\
\text { ic }\end{array}$ & $\begin{array}{c}\text { Statisti } \\
\text { c } \\
\end{array}$ & $\begin{array}{c}\text { Statist } \\
\text { ic }\end{array}$ & $\begin{array}{c}\text { Statist } \\
\text { ic }\end{array}$ & $\begin{array}{l}\text { Std. } \\
\text { Error }\end{array}$ & Statistic & $\begin{array}{c}\text { Statist } \\
\text { ic }\end{array}$ & $\begin{array}{c}\text { Statist } \\
\text { ic }\end{array}$ & $\begin{array}{l}\text { Std. } \\
\text { Error }\end{array}$ \\
\hline facebook & 33 & 3 & 2 & 5 & 136 & 4,12 & , 129 & ,740 &, 547 & 2,667 & ,798 \\
\hline instagram & 33 & 3 & 2 & 5 & 133 & 4,03 & 182 & 1,045 & 1,093 &,- 187 & ,798 \\
\hline Wa & 33 & 3 & 2 & 5 & 135 & 4,09 & 133 & ,765 & ,585 & ,332 & 798 \\
\hline Line & 33 & 4 & 1 & 5 & 114 & 3,45 & 180 & 1,034 & 1,068 & 1,033 & ,798 \\
\hline Telegram & 33 & 3 & 2 & 5 & 115 & 3,48 & 138 & 795 & ,633 &,- 315 & ,798 \\
\hline Youtube & 33 & 3 & 2 & 5 & 133 & 4,03 & 111 & ,637 & ,405 & 2,590 & ,798 \\
\hline Twitter & 33 & 3 & 2 & 5 & 122 & 3,70 & , 134 & ,770 & ,593 & , 489 & ,798 \\
\hline Valid N & 23 & & & & & & & & & & \\
\hline (listwise) & 30 & & & & & & & & & & \\
\hline
\end{tabular}

Sumber: Hasil Olah Data SPSS 23, 2020

Berdasarkan hasil uji statistik deskriptif pada tabel 5 menunjukkan jumlah responden (N) sebanyak 33 orang dengan memberikan penilaian terendah (minimum) 1 pada indikator pengembangan media sosial Line, yang artinya pengembangan jenis media sosial Line dinilai belum maksimal. Nilai tertinggi (maksimum) 5 terdapat pada seluruh jenis media sosial. Berdasarkan tabel di atas nilai SUM dari ke-tujuh indikator penilaian tertinggi pada jenis media sosial Facebook berjumlah 136. Media sosial facebook yang digunakan sebagai sarana promosi oleh UMKM Jawet dan Arep diniali memiliki poin promosi yang lebih efektif, sebab media sosial ini juga kali pertama yang digunakan UMKM Jawet Sama Arep dalam media brand image. Jangkauan pengunjung profil UMKM lebih banyak melalui media sosial Facebook. Sedangkan pada hasil uji kurtosis menunjukkan dua aspek kriteria penilaian belum berdistribusi secara baik yakni pada indikator facecook $=2,667$, media sosial line $=1,034$, dan media sosial Youtube $=2,590$. Seperti yang diketahui bahwa nilai kurtosis yang berdistribusi dengan baik jika hasil uji statistik semakin mendekati angka 0 . Sedangkan ketiga indikator pada aspek jenis media sosial tersebut lebih besar dari nilai 0 , sehingga dapat disimpulkan ketiga indikator tersebut belum terdistribusi dengan baik.

\subsubsection{Hasil Analisis Kriteria Penilaian Aspek Kesesuaian Materi Produk}

Di dalam penelitian research and development penilaian kesesuain materi produk menjadi salah satu indikator yang penting. Pada sub bab penelitian ini kesesuaian materi dikorelasikan dengan media yang dikembangkan. Adapun indikator penilaian yaitu: (1) 
tingkat kesesuaian materi desain dengan produk UMKM; (2) materi produk yang digunakan tidak menyimpang; dan (3) materi desain sesuai dengan kegunaan dari produk UMKM. Berikut merupakan hasil analisis uji yang digunakan yakni mengukur nilai kurtosis dari data penilaian berdasarkan jenis-jenis media sosial yang dikembangkan oleh UMKM Jawet Sama Arep.

Tabel 6. Descriptive Statistics Penilaian Kesesuain Produk

\begin{tabular}{|c|c|c|c|c|c|c|c|c|c|c|c|}
\hline & $\mathrm{N}$ & Range & $\begin{array}{c}\text { Minimu } \\
\mathrm{m}\end{array}$ & $\begin{array}{c}\text { Maximu } \\
\mathrm{m}\end{array}$ & Sum & \multicolumn{2}{|c|}{ Mean } & $\begin{array}{c}\text { Std. } \\
\text { Deviation }\end{array}$ & $\begin{array}{c}\text { Varian } \\
\text { ce } \\
\end{array}$ & \multicolumn{2}{|c|}{ Kurtosis } \\
\hline & $\begin{array}{c}\text { Statisti } \\
\mathrm{c} \\
\end{array}$ & $\begin{array}{c}\text { Statisti } \\
\mathrm{c} \\
\end{array}$ & $\begin{array}{c}\text { Statisti } \\
\mathrm{c} \\
\end{array}$ & Statistic & $\begin{array}{c}\text { Statisti } \\
\mathrm{c} \\
\end{array}$ & $\begin{array}{c}\text { Statisti } \\
\mathrm{C} \\
\end{array}$ & $\begin{array}{l}\text { Std. } \\
\text { Error }\end{array}$ & Statistic & $\begin{array}{c}\text { Statisti } \\
\text { c } \\
\end{array}$ & $\begin{array}{c}\text { Statisti } \\
\text { c } \\
\end{array}$ & $\begin{array}{l}\text { Std. } \\
\text { Error }\end{array}$ \\
\hline indikator_1 & 33 & 3 & 2 & 5 & 132 & 4,00 & 107 & ,612 & ,375 & 3,131 & 798 \\
\hline indikator_2 & 33 & 2 & 3 & 5 & 145 & 4,39 & ,097 & ,556 & ,309 &,- 891 & 798 \\
\hline indikator_3 & 33 & 1 & 4 & 5 & 140 & 4,24 & , 076 & ,435 & 189 &,- 443 & 798 \\
\hline Valid N & 33 & & & & & & & & & & \\
\hline (listwise) & & & & & & & & & & & \\
\hline
\end{tabular}

Sumber: Hasil Olah Data SPSS 23, 2020

Dari hasil uji statistik deskriptif pada tabel 6 menunjukkan jumlah responden $(\mathrm{N})$ sebanyak 33 orang dengan memberikan penilaian terendah (minimum) 2 pada indikator tingkat kesesuaian materi desain dengan produk UMKM, yang artinya pada salah satu media sosial yang dikembangkan sebagai sarana promosi brand image dinilai belum relevan. Nilai tertinggi (maksimum) 5 terdapat pada seluruh indikator penilaian kesesuain desain media dengan produk. Berdasarkan tabel di atas nilai SUM dari ke-tiga indikator penilaian tertinggi pada materi produk pada desain media tidak menyimpang berjumlah 145 . Hal ini tentunya dikarenakan fokus materi sesuai dengan produk yang dihasilkan oleh UMKM Jawet Sama Arep. Pada hasil uji kurtosis menunjukkan dua aspek kriteria penilaian belum berdistribusi secara baik yakni pada indikator tingkat kesesuaian materi desain dengan produk UMKM = 3,131. Seperti yang diketahui bahwa nilai kurtosis yang berdistribusi dengan baik jika hasil uji statistik semakin mendekati angka 0. Sedangkan ketiga indikator pada aspek jenis media sosial tersebut lebih besar dari nilai 0, sehingga dapat disimpulkan ketiga indikator tersebut belum berdistribusi dengan baik.

\section{Pembahasan}

Brand image adalah seperangkat keyakinan pada suatu nama, simbol atau desaign dan kesan yang dimiliki seorang terhadap suatu merek yang diperoleh berdasarkan informasi tentang fakta-fakta yang kemudian menggunakan merek tersebut, sehingga kesan yang 
muncul ini relatif jangka panjang yang terbentuk dalam benak konsumen. Citra (image) merupakan persepsi masyarakat terhadap perusahaan atau produknya. Image yang baik tentang produk akan menguntungkan perusahaan, karena konsumen secara tidak sadar akan merekomendasikan produk kepada orang lain. Sayangnya, sebelum dikembangkannya desain promosi dengan media sosial untuk hasil produk UMKM Jawet Sama Arep, kondisi citra (image) dari produk UMKM dinilai masih dikenal oleh masyarakat lokal saja, khususnya masyarakat Kabupaten Pulang Pisau. Keadaan tersebut mempengaruhi UMKM tidak dapat berkembang karena masih naik turunnya penjualan serta belum dibangunnya brand image Sehingga, hal ini tidak membantu meningkatkan kuantitas produksi dari UMKM sendiri. Maka dari itu dengan melihat peluang perkembangan teknologi digital yang cukup pesat ini, pelaku usaha pada UMKM Jawet Sama Arep mengembangkan desain promosi dengan menggunakan media sosial untuk membangun brand image agar lebih dikenal masyarakat luas.

Dalam membangun brand image, UMKM Jawet Sama Arep menerapkan tiga pilar komponen utama antara lain: (1) Corporate image (citra pembuat); (2) User image (citra pemakai); (3) Product image (citra produk). Alat pemasaran lainnya yang digunakan dalam membangun brand image yaitu dengan membentuk logo dan memberikan kemasan yang menarik beserta label sebagai ciri atau indentitas dari suatu produk UMKM Jawet Sama Arep. Dengan terbentuk citra dari suatu produk, maka masyarakat luas akan lebih mengenal produk tersebut. Media sosial memungkinkan pemasar membentuk suara publik, hadir di Web, dan memperkuat kegiatan komunikasi lainnya. Media sosial sendiri merupakan wadah yang dirancang dengan menggunakan pemanfaatan kecanggihan teknologi. Kehadiran internet dalam perangkat komputer, bahkan sistem telepon cerdas, di kehidupan sehari-hari memungkinkan manusia untuk berkomunikasi dengan manusia lainnya tanpa memperdulikan batas waktu dan tempat serta mengakses, mengumpulkan, dan menyimpan informasi yang dibutuhkan. Hal tersebut senada dengan pendapat Kotler (2012) menjabarkan serangkaian kemampuan internet bagi perusahaan dalam bidang pemasaran; antara lain, sebagai saluran informasi dan penjualan yang berpengaruh tinggi, sebagai alat untuk mengumpulkan informasi pasar secara menyeluruh, menggunakan jejaring sosial untuk mengkomunikasikan pesan merek, dan sebagai saluran pengiriman kupon serta sampel produk perusahaan. Sehingga, hal tersebut menjadikan peran media sosial telah mengubah cara masyarakat berkomunikasi dan mencari informasi. Menurut Nielsen (2011) 
Media sosial juga mengubah cara konsumen berkomunikasi dan berbagi informasi tentang merek sehingga kini konsumen mampu berdiskusi, beropini, dan membagi pengalaman mereka dengan merek tertentu.

Dengan memanfaatan media sosial artinya menyajikan konten-konten menarik sebagai sarana promosi dan mengkomunikasikan sebuah produk. Pemanfaatkan fitur-fitur yang tersedia di media sosial, seperti video dan foto, hal tersebut dilakukan guna menginformasikan bentuk produk kepada khalayak banyak. Media sosial juga dapat mendorong perusahaan untuk tetap inovatif dan relevan melalui kedekatan mereka seharihari. Hal inilah yang menjadi daya tarik penulis untuk mengembangkan brand image UMKM sebagai sarana promosi dengan menggunakan media sosial. Adapun media sosial yang dimanfaatkan yaitu: Whatsapp, Facebook, Instagram, Line, Telegram, Youtube, dan Twitter. Penggunaan media sosial menambah nilai atraktivitas dari sebuah produk dan menambah tingkat kedekatan konsumen dengan produk tersebut. Karena itu, banyak perusahaan kini menerapkan strategi untuk mempengaruhi tingkat keterlibatan komunikasi merek antar konsumen. Dengan demikian, mereka menciptakan nilai atraktivitas dan keinginan konsumen untuk membeli produk tersebut. Penggunaan media sosial juga memungkinkan perusahaan untuk mengumpulkan pemikiran konsumen terhadap produk atau jasa yang mereka tawarkan, mulai dari preferensi konsumen, kelebihan produk, hingga kelemahan produk. Hal ini didukung Irianto (2015) pemanfaatan media sosial dapat meningkatkan citra sebuah merek UMKM untuk mengenalkan, mengembangkan dan merawat merek mereka.

\section{SIMPULAN}

Berdasarkan informasi yang diperoleh dari pengurus UMKM Jawet Sama Arep bahwa jumlah produk yang diproduksi sejak tahun 2008-2019 relatif mengalami kenaikan dan juga penurunan di tahun yang berbeda. Berdasarkan hal tersebut pengelola UMKM membuat penelitian dengan mengembangkan media brand image tujuannya untuk dapat mengenalkan produk UMKM Jawet Sama Arep, juga dapat menaikan produksi dari hasil UMKM tersebut.

Penelitian ini dengan melakukan pengembangan brand image melalui sosial media ini juga dapat membantu meweujudkan tujuan dari UMKM sendiri sebagai usaha mandiri. Sehingga, dapat disimpulkan bahwa capaian brand image pada komponen corporate image, user image, dan product image dengan memanfaatkan media sosial dapat tercapai dengan baik, dibandingkan sebelum menggunakan media sosial. Peluang perkembangan teknologi 
digital yang cukup pesat ini, pelaku usaha pada UMKM Jawet Sama Arep mengembangkan desain promosi dengan menggunakan media sosial berupa Facebook, Instagram, Line, Youtube, Whatsapp, Telegram, Twitter.

\section{DAFTAR RUJUKAN}

Haidar, A. (2016). Strategic Role of E-Commerce and MSMEs in MEA. Kompasiana. http://www.kompasiana.com/alvin123/peran-strategis-e-commerce-dan-umkm-dalammea_5861b5d961afbdea0ef3ecc8.

Hanaysha, J. (2016). The importance of social media advertisements in enhancing Brand equity: a study on fast food restaurant industry in Malaysia. International Journal of Innovation and Technology Management, 6(1), 46-51. https://doi.org/10.18178/ijimt.2016.7.2.643

Hanaysha, J. (2018). An examination of the factors affecting consumer's purchase decision in the Malaysian retail market. PSU Research Review, 2(1), 7-23. https://doi.org/10.1108/PRR-08-2017-0034

Harini, C., Darsin, D., \& Praptono, S. (2017). Pengembangan pemasaran kewirausahaan dalam upaya meningkatkan kinerja perekonomian unit usaha mikro kecil menengah di Kota Semarang. 537-549.

Hinz, O., Skiera, B., Barrot, C., \& Becker, J. U. (2011). Seeding strategies for viral marketing: an empirical comparison. Journal of Marketing, 75(6), 55-71.

Irianto, A. B. P. (2015). Pemanfaatan Social Media Untuk Meningkatkan Market Share UKM. Jurnal Teknomatika, 8(1), 1-12.

Kaplan, A. M., \& Haenlein, M. (2010). Users of the world, unite! the challenges and Opportunities of Social Media. Business Horizons, 53(1), 59-68.

Kotler, P. (2012). Marketing management (14th ed.). Pearson Prentice Hall.

Kotler, P., \& Keller, K. L. (2016). Marketing Management (15th ed.). Pearson Education.

Kremer, F., \& Catherine, V. (2012). How Store Brands Build Retailer Brand Image.” International Journal of Retail \& Distribution Management. International Journal of Retail \& Distribution Management, 40(7), 528-543. https://doi.org/10.1108/09590551211239846

Martínez, Patricia, Andrea, P., and Ignacio, R. (2014). CSR Influence on Hotel Brand Image and Loyalty. Academia Revista Latinoamericana de Administración, 27(2), 267-283. https://doi.org/10.1108/ARLA-12-2013-0190 
Nielsen. (2011). The digital media habits and attitudes of seoutheast asian consumers.

Ökten, N. Z., Okan, E. Y., Arslan, Ü., \& Güngör, M. Ö. (2019). The effect of brand value on economic growth: A multinational analysis. European Research on Management and Business Economics, 25(1), 1-7. https://doi.org/https://doi.org/10.1016/j.iedeen.2018.11.002

Rindell, A., \& Oriol, I. (2014). Context and Time in Brand Image Constructions. Journal of Organizational Change Management, 27(5), 756-768. https://doi.org/10.1108/JOCM09-2014-0172

Schmitt, P., Skiera, B., \& Bulte, C. Van den. (2011). Referral Programs and Customer Value. Journal of Marketing, 75(1), 46-59. https://doi.org/10.2307/25764294

Severi, E., Ling, K. C., \& Nasermoadeli, A. (2014). The impacts of electronic word of mouth on brand equity in the context of social media. International Journal of Business and Management, 9(8), 84-96. https://doi.org/10.5539/ijbm.v9n8p84

Stanton, W.J., Etzel, M. J., \& Walker, B. . (2007). Marketing (14th ed.). McGraw-Hill.

Sudarwati, Y., \& Satya, V. E. (2013). Strategi pengembangan merek usaha mikro, kecil, dan menengah. Jurnal Ekonomi \& Kebijakan Publik, 4(1), 89-101. https://doi.org/10.22212/jekp.v4i1.70

Sugiyono. (2016). Metode Penelitian Kuantitatif, Kualitatif dan R\&D. PT Alfabeta.

Tim Puslitjaknov. (2008). Metode Penelitian Pengembangan. Departemen Pendidikan Nasional.

Tsimonis, G., \& Sergios, D. (2014). Brand Strategies in Social Media. Marketing Intelligence \& Planning, 32(3), 328-344. https://doi.org/10.1108/MIP-04-2013-0056 